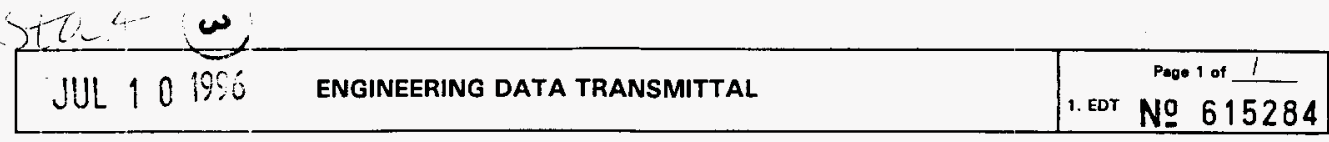

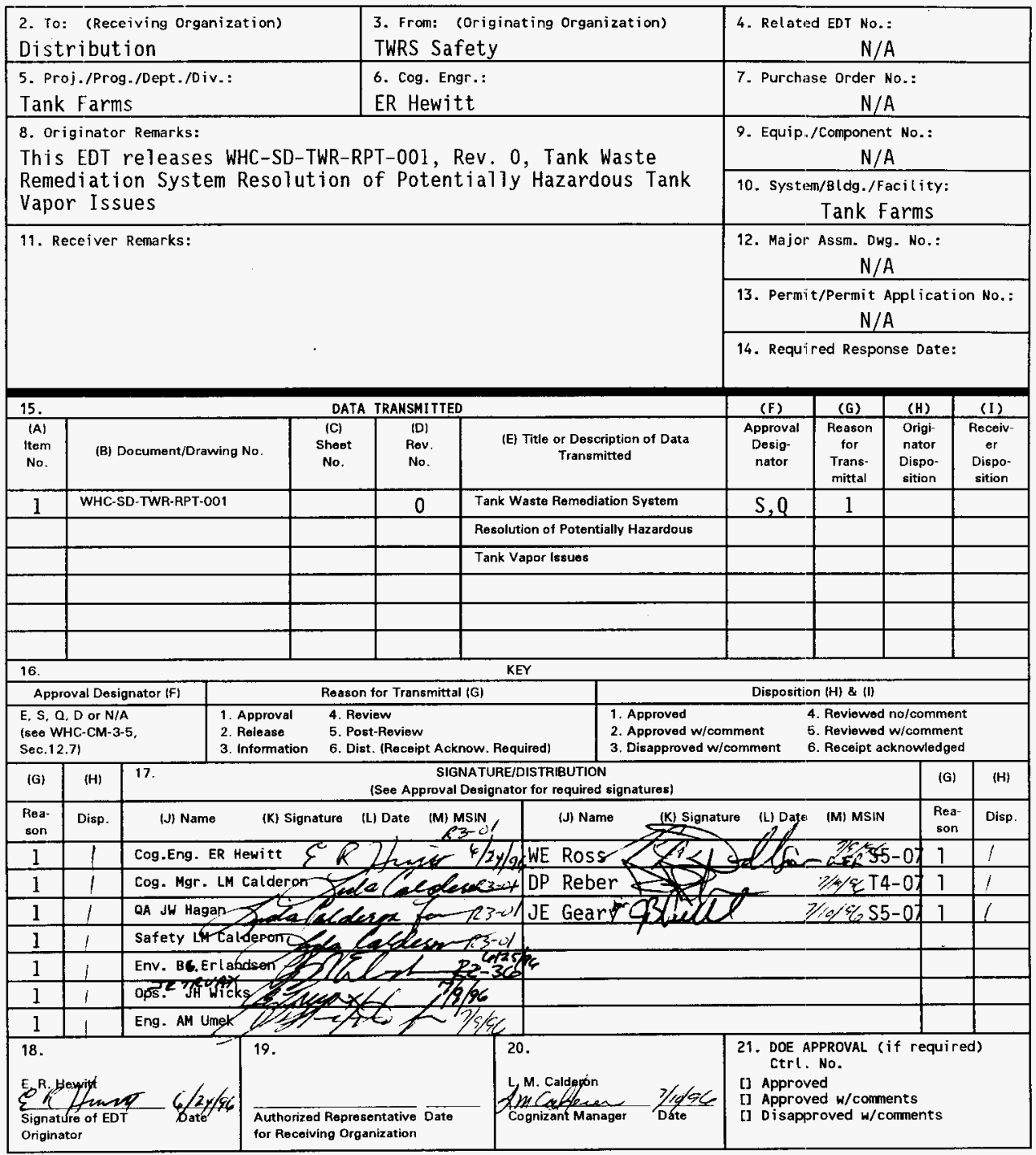




\title{
Tank Waste Remediation System Resolution of Potentially Hazardous Vapor Issues
}

\author{
Elton R. Hewitt
}

Westinghouse Hanford Company, Richland, WA 99352

U.S. Department of Energy Contract DE-AC06-87RL10930
EDT/ECN: 615284
Org Code: $74 \mathrm{G} 10$
UC: UC-2070
B\&R Code: EW3120075
Charge Code: DIM7l
Total Pages: 22 is cme $7 /$ rots

Key Words: Tank Farms, Health, Safety, Vapors

Abstract: This report documents the resolution of industrial health and safety issues regarding potentially hazardous tank vapors in the Hanford 200 Area Tank Farms. It also summarizes the tasks and controls which have been implemented and demonstrates that with the present work controls in place, an unacceptable inhalation risk to workers from tank farm vapors does not exist.

TRADEMARK DISCLAIMER. Reference herein to any specific comercial product, process, or service by trade name, trademark, manufacturer, or otherwise, does not necessarily constitute or imply its endorsement, recommendation, or favoring by the United States Government or any agency thereof or its contractors or subcontractors.

Printed in the United States of America. To obtain copies of this document, contact: WHC/BCS Document Control Services, P.O. BOx 1970, Mailstop H6-08, Richland WA 99352, Phone (509) 372-2420; Fax (509) 376-4989.
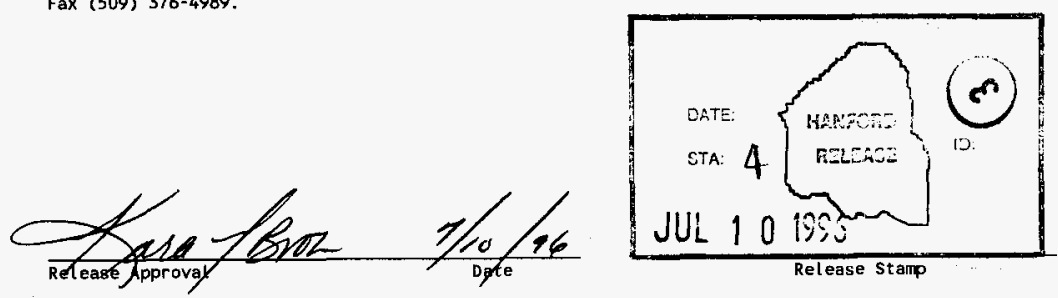

\section{Approved for Public Release}


WHC-SD-TWR-RPT-001

REVISION 0

\section{TANK WASTE REMEDIATION SYSTEM \\ RESOLUTION OF POTENTIALLY HAZARDOUS \\ TANK VAPORS ISSUE}

Elton R. Hewitt

June 24, 1996

Westinghouse Hanford Company

Richland, Washington 


\section{TABLE OF CONTENTS}

1.0 PURPOSE OF REPORT $\ldots \ldots \ldots \ldots \ldots \ldots \ldots \ldots \ldots \ldots \ldots \ldots \ldots$

1.1 EXECUTIVE SUMMARY $\ldots \ldots \ldots \ldots \ldots \ldots \ldots \ldots \ldots \ldots \ldots$

1.2 INDEPENDENT REVIEWS $\ldots \ldots \ldots \ldots \ldots \ldots \ldots \ldots \ldots \ldots \ldots \ldots$

2.0 RESPONSE TO POTENTIALLY HARMFUL VAPORS $\ldots \ldots \ldots \ldots \ldots \ldots$

2.1 ADMINISTRATIVE CONTROLS $\ldots \ldots \ldots \ldots \ldots \ldots \ldots \ldots \ldots \ldots$

2.2 INDUSTRIAL HYGIENE MONITORING $\ldots \ldots \ldots \ldots \ldots \ldots \ldots$

3.0 DECISION CRITERIA/REVISION OF CONTROLS $\ldots \ldots \ldots \ldots \ldots \ldots$

3.1 COMMUNICATION OF CHANGES $\ldots \ldots \ldots \ldots \ldots \ldots \ldots \ldots \ldots \ldots$

3.2 PROGRESS IN RESPIRATORY PROTECTION REDUCTIONS $\ldots \ldots \ldots \ldots \ldots$

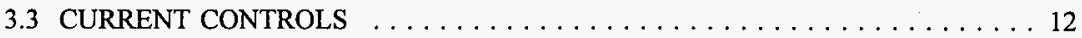

4.0 EMPLOYEE EXPOSURE INCIDENTS $\ldots \ldots \ldots \ldots \ldots \ldots \ldots \ldots \ldots$

5.0 OTHER TANK VAPOR ACTIVITIES $\ldots \ldots \ldots \ldots \ldots \ldots \ldots \ldots \ldots \ldots \ldots$

5.1 VAPOR MIXING SYSTEM ON TANK $241-\mathrm{C}-103 \ldots \ldots \ldots \ldots \ldots \ldots$

5.2 TANK VAPOR DATA STATISTICAL EVALUATION $\ldots \ldots \ldots \ldots \ldots \ldots$

6.0 CONCLUSIONS $\ldots \ldots \ldots \ldots \ldots \ldots \ldots \ldots \ldots \ldots \ldots \ldots \ldots \ldots \ldots \ldots \ldots$

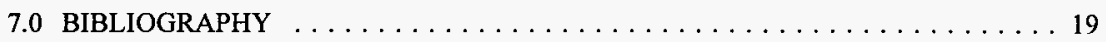


WHC-SD-TWR-RPT-001

Revision 0

Page 1

TANK WASTE REMEDIATION SYSTEM

RESOLUTION OF POTENTIALLY HAZARDOUS TANK VAPORS ISSUE

\subsection{PURPOSE OF REPORT}

This report documents the resolution of industrial health and safety issues regarding potentially hazardous tank vapors in the Hanford 200 Area Tank Farms. It also summarizes the tasks and controls which have been implemented and demonstrates with a high degree of scientific certainty that with the present work controls in place, an unacceptable inhalation risk to workers from tank farm vapors does not exist.

The intended users of this report include Tank Farm Workers, WHC Management, the Department of Energy, and the Public. The conclusions are that the potential for hazardous vapor exposure is now understood and the present control measures are adequate. Additional tank headspace monitoring or vapor exhausting systems are not needed to prevent employee overexposure to hazardous vapors.

\subsection{EXECUTIVE SUMMARY}

In response to safety concerns in 1992, WHC implemented a program to protect employees from hazardous vapor exposures during work in the Hanford 200 Area Tank Farms. Because the nature of the vapors were unknown, a decision was made to implement controls for the farms that were similar to those employed at an uncontrolled hazardous waste site.

The strategy consisted of the following elements:

- Immediately implement tank farm work controls to prevent employee overexposure to vapors

- Develop a Tank Farm Health and Safety Plan based on 29 CFR 1910.120 requirements

- Conduct vapor monitoring and sampling of employees working in tank farms

- Characterize the tank headspace vapors to determine the potential for employee overexposure to vapors

- Based on analysis of worker monitoring and headspace data, revise the control measures to protect employee health without being overly restrictive 
After four years, sufficient information has been collected to evaluate the effectiveness of the strategy and the resulting control measures. The conclusion is that the issues associated with protecting employees from overexposure to vapors during tank farm work are defined and controlled.

Employee exposure incidents have virtually ceased due to implementation of controls around potential vapor release points and as a result of better communications regarding vapor odors and risks. Additional studies are not needed to verify these conclusions. Rather, continuing improvements in the conduct of operations should focus on maintaining the safe work environment while being open to new technologies which offer more cost effective approaches to employee protection.

It is concluded that tank farm worker health and safety considerations caused by the inhalation of potentially hazardous vapors have been resolved. However, other questions associated with headspace vapors, such as gas flammability and the presence of organic solvent pools are outside the scope of this document.

\subsection{INDEPENDENT REVIEWS}

Throughout resolution of the hazardous vapors issues, the strategies, methods, results, conclusions, and recommended changes have been reviewed and approved by a number of independent bodies. These are:

THE OCCUPATIONAL SAFETY AND HEALTH WASTE TANK ADVISORY PANEL This panel consists of nationally-recognized experts in the field of industrial health and safety.

THE TANK FARM OPERATIONS ADVISORY COUNCIL

This group consists of WHC operational, safety, and bargaining unit representatives.

\section{THE TANK FARM TANK VAPOR TASK TEAM}

This team encompasses Industrial Hygiene and bargaining unit representatives from across the Hanford Site. Contractors represented included PNNL, HEHF, WHC, and DOE-RL.

\subsection{RESPONSE TO POTENTIALLY HARMFUL VAPORS}

In the past, several vapor exposure incidents have occurred in Hanford Tank Farms. The most serious occurred in July 1987, when three employees were exposed to vapors at tank $\mathrm{C}-103$. At the time, a temporary exhauster had been installed on the tank. While working on the exhauster, two employees were exposed to high vapor concentrations and were subsequently hospitalized. 
This occurrence was highly atypical of other exposure incidents, and would be similar to the exposure a person could receive from breathing air directly from the tank headspace. The event demonstrates that without appropriate controls, direct exposure to potentially harmful vapors can occur and cause symptoms of vapor overexposure.

During the period 1987-1991, many less serious vapor exposure incidents occurred. Employees involved in these incidents reported to first aid where they generally reported odors or symptoms of nausea. Most of these exposures were referred to HEHF or a local hospital for evaluations. In almost all cases, there were no medical findings to indicate the employee had been overexposed to vapors. When an industrial hygiene technician investigated, no evidence could be found to verify that an overexposure had occurred. These incidents created concern among employees, their managers, and the DOE as to whether employees could work in tank farms without being overexposed to potentially hazardous vapors.

Interest peaked early in 1992. On January 28, five construction employees reported to first aid after having smelled strong odors and experiencing symptoms of exposure during work near one of the tank farms. Investigation of this incident revealed that the source of the odors was a battery that had ruptured due to being improperly connected.

Nevertheless, because of continuing exposure incidents, a Type B Investigation of Hanford Tank Farms Vapor Exposures was initiated by the Richland Field Office of the U.S. Department of Energy. Concurrent with this investigation, a number of measures were taken to deal with vapor exposures.

\subsection{ADMINISTRATIVE CONTROLS}

The first action was a WHC management directive that required employees working in several specified tank farms to use supplied air for all work. Employees working in the remaining farms were required to have an industrial hygiene technician and vapor monitoring equipment present at all times. This measure was taken to immediately protect employee health during tank farm work. The action provided an interim solution to protect the employees until the problem could be further defined and mitigated.

A WHC management directive requiring additional controls was implemented in March, 1992. At that time, all employees working in three single-shell tank farms (BX, BY and C farms) were required to wear supplied air for all tank farm work. In addition, employees working near selected tanks in three additional farms ( $\mathrm{T}, \mathrm{TX}$, and $\mathrm{TY}$ ) were also required to use supplied air for all work. For all other single-shell tanks, an industrial hygiene technician with monitoring instrumentation would accompany each work group during tank farm work and continually evaluate the air quality while the work was being done. These actions were 
felt to be necessary to protect employee health until sufficient sampling and monitoring data were collected to define employee vapor risks and revise the control measures.

Simultaneous with the increased use of personal protective equipment, a decision was made to treat tank farms as if it was an uncontrolled hazardous waste site. This was based on the fact that data concerning employee vapor exposure levels during tank farm work were generally unavailable and tank headspace vapors had not yet been characterized. As part of this protective action, a Tank Farm Health and Safety Plan (HASP) was prepared in accordance with 29 CFR 1910.120.

The initial release of the HASP was completed in June 1993. This document served to identify known safety and health hazards in tank farms and to present the control measures necessary to mitigate the hazards. The HASP provided a compliance document and an educational tool to help employees familiarize themselves with tank farm hazards. The HASP has been updated periodically since the initial release, and serves as the primary administrative control for conducting safe work in the tank farms.

\subsection{INDUSTRIAL HYGIENE MONITORING}

Another protective measure was to assign an industrial hygienist to address the tank farm vapor issue. The objective was to evaluate the risk of exposure to hazardous vapors, and based on this evaluation, recommend reductions in the use of personal protective equipment and industrial hygiene monitoring where this could be done safely. The effort was to safeguard employee health while implementing appropriate and necessary controls.

The major elements of the industrial hygiene strategy included gathering vapor data from area surveys, personnel monitoring, vapor source measurements, and from tank headspace vapor sampling. Each of the four monitor programs provided a partial understanding of the exposure situation. Taken together they allow Industrial Hygiene to make decisions regarding worker health and safety and to employ appropriate protective measures during work in tank farms. The types of industrial hygiene monitoring are described below.

Area Surveys

Beginning in March of 1992, area vapor monitoring was instituted in the farms. These local surveys recorded the levels of vapors present in the farms during routine work tasks. An organic vapor meter (OVM) was used to determine organic vapor levels, and substancespecific sorbent tubes were used for a limited number of inorganic chemicals. To date, area monitoring at approximately 2000 locations has been done in support of individual tank farm work packages. 
Area monitoring documented the vapor levels which were present when work was being performed near the underground storage tanks. In many cases, the work involved opening one or more of the tank risers, thus providing additional release points and increasing the potential for the presence of vapors. Results from area surveys near these release points indicate that high levels of organic vapors (up to $100 \mathrm{ppm}$ ) and ammonia (up to $500 \mathrm{ppm}$ ) were being released from some of the tanks. However, measurements obtained in the area where employees were working indicated organic vapor levels were generally less than $2 \mathrm{ppm}$ and ammonia levels less than 25 ppm.

The area monitoring confirmed that ammonia levels exceeding the Occupational Safety and Health Administration (OSHA) Permissible Exposure Limit (PEL) of $25 \mathrm{ppm}$ and the Short Term Exposure Limit (STEL) of $35 \mathrm{ppm}$ were present near release points in some tank farms. Area monitoring also documented that employees were not exposed to vapor levels which were above the instantaneous action levels of $2 \mathrm{ppm}$ organic vapor or $25 \mathrm{ppm}$ ammonia. If levels above these values were obtained where employees were to work, the Tank Farm Health and Safety Plan dictates that either supplied air would be used, or the job would not be performed.

\section{Personal Sampling}

Personal monitoring measurements are valuable for three reasons. First, they provide an indication of actual, not estimated or calculated exposure levels. Second, these levels can be compared against existing standards for exposure to determine if employees are being overexposed to vapors. Third, the measurements provide excellent feedback on the effectiveness of the implemented exposure controls in reducing employee exposure levels. To accurately assess individual employee exposures, personal sampling was initiated in January 1993.

Personal sampling consists of attaching a device to an employee which samples the air in the breathing zone during the performance of the work task. Specific chemicals which could be identified include hydrogen cyanide, acetone, butanol, ammonia, and nitrous oxide. In addition, broad-spectrum organic sampling was used to detect the presence of any of several hundred organic chemicals that may be escaping from the tanks. The personal sampling results include both contaminants present and average concentration exposures during the work tasks.

Over 350 personal samples have been collected from 18 tank farms during all types of work activities. Some activities involved opening the tanks, thus increasing the potential for vapor releases. These samples, and the tasks they were associated with, varied in length from twenty minutes to over five hours. From these samples, an eight-hour PEL can be calculated, and an STEL can be estimated. Since the samples were collected for longer than fifteen minutes, an STEL was not determined, but can be estimated by assuming that the exposure level was constant for the duration of the task. The highest exposure levels 
obtained from the personal sampling are shown on Table 1. The table includes the lower of the Occupational Safety and Health Administration (OSHA) Permissible Exposure Limit (PEL) or American Conference of Governmental Industrial Hygienists (ACGIH) Threshold Limit Value (TLV) PEL/TLV for the material, as well as the OSHA Short Term Exposure Limit (STEL). The odor threshold is also provided in this table for reference.

Table 1 - Maximum 8-hour Personal Exposure Levels

\begin{tabular}{|l|l|l|l|l|l|}
\hline Contaminant & $\begin{array}{l}\text { Maximum 8- } \\
\text { hour Exposure, } \\
\text { ppm }\end{array}$ & $\begin{array}{l}\text { Lower of 8- } \\
\text { hr PEL/TLV, } \\
\text { ppm }\end{array}$ & $\begin{array}{l}\text { Maximum } \\
\text { Estimated } \\
\text { STEL, ppm }\end{array}$ & $\begin{array}{l}\text { OSHA } \\
\text { ACGIH } \\
\text { STEL, ppm }\end{array}$ & $\begin{array}{l}\text { Odor } \\
\text { Threshold, } \\
\text { ppm }\end{array}$ \\
\hline Ammonia & 2.6 & 25 & 10.3 & 35 & 17 \\
\hline Nitrous Oxide & 3.9 & 50 & 9 & 150 & Not Given \\
\hline 1-Butanol & 0.4 & 50 (Ceiling) & 1.5 & 50 & 1.2 \\
\hline
\end{tabular}

The maximum personal exposure level which was measured for any of the three contaminants is about $10 \%$ of the allowable 8-hour exposure level, and about $30 \%$ of the STEL. This indicates that tank farm vapor exposures are well-controlled, and consistently within acceptable levels. It should be noted that personal protective equipment was being used while this sample was being collected. As such, the employees were not exposed to this concentration. Although at the release points, the vapors escaping from some of the tanks are considerably above acceptable limits for exposure, due to the exposure control methods being used, no overexposures are occurring.

\section{Source Monitoring}

Monitoring at vapor release points was added in March 1993. This task was to identify all locations where vapors may be escaping from a tank, and to measure the highest levels of contaminants present. Source monitoring was performed using an OVM and solid-sorbent tubes similar to area monitoring. Nearly 1800 source measurements have been performed within the single-shell tank farms.

The source monitoring method used is generally not vapor specific, but does indicate the presence of ammonia when high vapor levels are being released, Based on source monitoring, 34 of the single-shell tanks were determined to be releasing significant amounts of vapors. These tanks had organic vapor levels ranging from 10 to $104 \mathrm{ppm}$ total organics, and ammonia levels of up to $700 \mathrm{ppm}$. It should be noted that these measurements were taken right at the vapor release point, and are NOT indicative of either work area or personnel 
exposure levels. Rather, they confirm that potentially harmful vapors are being released from the tanks and they indicate that the levels at the release point present a hazard to unprotected employees working in the area.

To protect employees in these areas, barricades were erected around the release points and entry precautions have been implemented for all employees whose work required them to enter the barricaded areas. These precautions included both vapor monitoring and/or personal protective equipment. The barricades were erected to guarantee that vapors had diluted sufficiently so that employees working outside the barricades would not be subject to concentrations higher than the PEL/TLV for the vapors.

Headspace Characterization

Tank headspace sampling was initiated in August 1992 to determine the vapors present in the tanks. The initial focus was on those tanks judged to present the greatest hazards (watchlist tanks). Later sampling provided additional information on both chemical species and vapor levels present in the tanks. The sampling and analytical procedures employed provided information on hundreds of compounds that might be present, including both the specific chemical species and the concentration present within the tanks.

No employees actually work inside the tank headspace. As such, a direct comparison between tank headspace vapor levels and allowable exposure levels can be misleading. However, tank headspace data establish upper bounds for vapor exposure levels. The headspace data can thus be compared against exposure limits to estimate the potential for an employee overexposure in a worst-case situation. Because of dilution, the levels present outside the tanks will not be higher than the levels inside the tanks. Although tank headspace data was not available during the early stages of the industrial hygiene data collection, headspace sampling and characterization has now been completed on 67 tanks.

A review of the headspace data indicates that only two compounds identified in the tank headspaces are routinely present at concentrations greater than five times the lower of the PEL/TLV for the material. These chemicals are ammonia and nitrous oxide. Several other chemicals identified in the tank headspace at low concentrations are potential carcinogens and no PEL/TLV has been assigned to these materials. Instead, exposure to these materials should be maintained at low levels to prevent unnecessary inhalation risks to employees.

While potential carcinogens have been identified as being present in the tank headspace, the levels observed are very low and should not pose a hazard to employees working in the area for two reasons. First, the concentration of these chemicals outside the tank headspace will be even lower than the level observed in the tank. Second, these chemicals are present at sufficiently low concentrations so that employees can be protected from overexposure by maintaining their ammonia exposure level below its PEL. By protecting employees from an 
excess exposure to ammonia, the resulting exposure level to the other materials would also be at acceptable levels.

Based on the tank headspace analysis, the maximum concentration of ammonia present in the sampled tanks is $793 \mathrm{mg} / \mathrm{m} 3$, or $1117 \mathrm{ppm}$ by volume and the maximum nitrous oxide concentration is $1720 \mathrm{mg} / \mathrm{m} 3$, or $940 \mathrm{ppm}$ by volume. The ACGIH TLV for ammonia for an 8-hour exposure is $17 \mathrm{mg} / \mathrm{m} 3$, or $25 \mathrm{ppm}$ by volume while the ACGIH TLV for nitrous oxide is $90 \mathrm{mg} / \mathrm{m} 3$, or $50 \mathrm{ppm}$ by volume.

Because the tank headspace results were not available when decisions were being made to revise control measures, revisions of tank farm entry controls were generally not based on tank headspace levels. These levels will be considered in making future decisions regarding entry level controls.

\subsection{DECISION CRITERIA/REVISION OF CONTROLS}

In the tank farms, source monitoring and area monitoring results indicate that vapors are escaping from the tanks at levels well above the OSHA PEL for ammonia. In contrast, personal sampling indicates the employees exposure levels are below the PEL, and have been since exposure control measures have been implemented.

After evaluating data from all sources, decisions can be made on the need for changes to the vapor exposure controls for each farm. If the new level of controls are different from the previous level, the revised controls are reviewed by the Worker Safety and Health Technical Advisory Panel, DOE-RL and other groups to assure the new controls provided adequate protection to employees. After approval, the new controls are implemented by presenting both the new controls and supporting data to the tank farm employees.

Because the potential for vapor exposures differ for each farm, each has been addressed individually. The need for representative data has resulted in extensive sample collection and monitoring activities for each farm. For the reduction or elimination of any farm's entry controls (i.e., respiratory protective equipment and required monitoring), the data has been reviewed to ensure the following requirements have been met:

1. Personal sampling data for that farm must show all measured levels for all contaminants to be less than the PEL. Currently this is demonstrated by showing that the average level from a group of samples was less than $1 / 10$ of the PEL.

2. Area monitoring data must confirm the personal sampling results. 
WHC-SD-TWR-RPT-001

Revision 0

Page 9

3. Source monitoring data using OVMs must indicate that no significant vapor releases, which are defined as greater than $10 \mathrm{ppm}$ are occurring at any of the potential vapor release points on any of the tanks. Since no PEL/TLV exists for total organics measured with an OVM, an "action level" of $10 \mathrm{ppm}$ was adopted as an indication of tank vapor release.

4. Tank headspace data (if available) shall be considered in evaluating the potential for vapor exposure. Personal monitoring must be performed on employees working near any tank where tank headspace analysis show chemical vapor levels in excess of the lower of the PEL/TLV.

When sampling and monitoring results for a farm met the criteria identified above and a review of vapor incident logs had been completed, recommended changes were made in respiratory protection and monitoring requirements. The exact recommendations varied from farm to farm, and were based on the levels and locations noted during monitoring. For example, when this strategy was employed at A Farm, all the tanks met the criteria except for Tanks 101 and 106, which exceeded the source monitoring response level of $10 \mathrm{ppm}$. Thus, the controls implemented for A Farm included the elimination of respiratory protection and area monitoring for access to all tanks except 101 and 106. A barrier was placed around the breather filter and respiratory protection requirements were established for entry into this area. These physical and administrative controls defined the respiratory protection measures.

\subsection{COMMUNICATION OF CHANGES}

Following review and approval of each proposed change in respiratory protection control, a letter of notification was transmitted to DOE RL. To ensure understanding of changes at the worker level, training sessions were conducted to explain industrial hygiene monitoring strategies, sampling results, and control measures employed in the reduction of respiratory protection equipment. Worker response to training sessions has been very positive, both in terms of the actions and the approach involved in the decision-making process.

Finally, documentation to support the respiratory protection changes has been incorporated into the Tank Farm Health and Safety Plan at each step, specifically involving modifications to the Safe Work Practice. The Safe Work Practice is also posted in each change trailer for easy reference by workers.

\subsection{PROGRESS IN RESPIRATORY PROTECTION REDUCTIONS}

Using the strategy mentioned above, the following is an overview of the progression and types of changes in respiratory protection requirements since February 1992. 
WHC-SD-TWR-RPT-001

Revision 0

Page 10

\begin{tabular}{|c|c|}
\hline Date of Change & Summary of Change \\
\hline February 1992 & Supplied Air and/or Monitoring Required \\
\hline June 1993 & $\begin{array}{l}\text { Reduced/Eliminated Monitoring Requirements for A, AX, B, } \\
\text { SX Farms }\end{array}$ \\
\hline September 1993 & $\begin{array}{l}\text { Reduced/Eliminated Monitoring Requirements for T, BX, BY } \\
\text { Farms }\end{array}$ \\
\hline January 1994 & $\begin{array}{l}\text { Reduced Requirement from Supplied Air to Monitoring for } \\
\text { FeCN Watchlist Tanks }\end{array}$ \\
\hline March 1994 & Further Reduction of Entry Requirements for BX, BY Farms \\
\hline April 1994 & Reduced Entry Requirements in C Farm \\
\hline June 1994 & $\begin{array}{l}\text { Reduced/Eliminated Monitoring Requirements for TX, TY, U } \\
\text { Farms }\end{array}$ \\
\hline
\end{tabular}

September 1994 Eliminated Monitoring Requirements for FeCN Watchlist Tanks

By September 1994, baseline industrial hygiene monitoring and sampling data had been collected on all single-shell tanks, and entry/monitoring requirements had been reduced in virtually all single-shell tank farms. Minor changes were made after September 1994 as additional sampling and monitoring data were evaluated. Tank headspace monitoring had only been performed on a few tanks by September 1994, and the data were generally not available for use in determining employee risk levels. Of necessity, this required that the adopted control measures be somewhat conservative.

When necessary, special measures are taken at the time respiratory protection changes are made specifically to address special employee concerns. An example of this is C Farm. Despite the fact that all monitoring data collected indicated that the respiratory protection requirements could be downgraded in C Farm, meetings with employees and managers indicated that some concerns remained. These concerns were based primarily on the fact that odors are often detectable in C Farm; it has a history of being the most odorous farm. Employees have been educated to the fact that odors can often be detected at levels far below those harmful to human health, however, a few employees were still concerned. 
WHC-SD-TWR-RPT-001

Revision 0

Page 11

In response to this heightened sensitivity to the odor issue, a special roving industrial hygiene technician was assigned to C Farm at the time that the respiratory protection reductions were made. In addition to pre-job briefings and facility orientation, this technician briefs workers entering the farm about the likelihood of odors being present in certain areas of the farm, and of his availability to evaluate any odors. This has immediately demonstrated that the odors detected do not represent a health hazard, and as a result numerous employee concerns were avoided and the employees' confidence that their health is not being compromised has been significantly increased.

\subsection{CURRENT CONTROLS}

In comparing current respiratory protection control requirements with those implemented in 1992, the following progress can be seen:

$\begin{array}{ll}\text { March } 1992 & \underline{\text { May } 1996} \\ 41 \text { Tanks - Supplied Air Required } & 2 \text { Tanks - Supplied Air Required } \\ 108 \text { Tanks - Monitoring Required } & 32 \text { Tanks - Monitoring Required in } \\ & \text { Small Area } \\ & 115 \text { Tanks - No Monitoring or } \\ \text { Supplied Air Required }\end{array}$

These reductions have been methodical and scientifically based using standard Industrial Hygiene practices. They ensure worker safety and health, reduce risk to workers from the physical strain of wearing supplied air respiratory protection, and allow for increased productivity.

In addition, tank headspace vapor characterization has been performed in many of the singleshell tanks. As of May 14, 1996, tank headspace sampling had been performed on 67 of these tanks. Data from this sampling effort is being used to provide a worst case scenario for employees working in the tank farms, since the tank vapor level in the work area should be less than or equal to the vapor level observed in the tanks.

An extensive analysis of the tank headspace data is currently in progress, but a preliminary analysis of the data shows that the vapor levels observed in the tank headspace are consistent with those observed during the industrial hygiene source monitoring program. As such, the tank headspace results generally support the control limits for work in the tank farms, since these controls were based on source monitoring results.

In summary, a good understanding of the chemical species and concentrations present in the tank headspace based on characterization efforts currently exists. Extensive data on the vapor 
levels present in the general work area and at the release points from the tanks has been generated. Employee exposure levels have been evaluated from personal sampling data on employees working in tank farms. When these data are taken as a whole, they present a good and consistent picture of the nature of the vapor hazard in tank farms.

As a result, appropriate control measures have been implemented to reduce the risk of vapor overexposure during tank farm work. These measures include both industrial hygiene monitoring and personal protective equipment to protect employees. The success of these measures is preventing employee overexposure is demonstrated by the low vapor exposure levels observed from personal samples collected on employees during tank farm work, and the lack of exposure incidents.

It should be noted that, when work activities require that a waste tank be opened by temporarily removing one or more of the riser or pit covers, industrial hygiene monitoring is performed at the potential release points by an industrial hygiene technician who is wearing supplied air. This precaution is necessary since headspace characterization has not been completed on all tanks, and opening a tank may increase the vapor releases from the tank. Once the potential for vapor release has been evaluated, appropriate controls including temporary barriers, monitoring, or protective equipment, are implemented to protect employees working at the tank.

\subsection{EMPLOYEE EXPOSURE INCIDENTS}

As noted earlier, many employee exposure incidents have occurred over the past several years at Hanford. An incident is defined as an employee either smelling an odor or observing some symptoms of overexposure to tank vapors. The employee would then go to the first aid station, and was either returned to work or sent to a medical facility for additional tests.

Prior to implementation of physical and administrative vapor exposure controls employee exposure incidents were common, with 35 such incidents occurring from 1987 through 1993. Although one of these incidents actually resulted in serious exposure symptoms, the majority consisted of an employee smelling an odor or feeling slightly nauseous and reporting to first aid. No observable signs of exposure were noted on these incidents, and test results to indicate overexposure (both medical and environmental) were negative.

It is believed that exposure incidents occurred primarily because of a heightened worker sensitivity due to the lack of information about the nature of tank vapors. Many workers were told that any vapors escaping from tanks were harmful and they might be injured or killed if they smelled such vapors. Given this and the fact that some tank vapors will have odors even though exposure levels are well below acceptable OSHA levels, it is not surprising that many vapor exposure incidents occurred. 
Beginning in 1993, employees were presented with results from the various sampling and monitoring programs being performed. These presentations included a discussion of tank odors, and their relationship to vapor emission levels. One of the purposes of the presentations was to familiarize the workers to tank vapor odors by providing accurate information on tank vapor levels. Another measure that was implemented was an odor response hotline, where employees could call in 24 hours a day and have an industrial hygiene technician respond to check out the source of an odor. These measures have been effective in reducing employee fears, and the number of exposure incidents.

Since September of 1995, only one odor incident has occurred in the tank farms. This incident occurred when an employee was sitting on a valve pit cover in $U$ farm and received an ammonia exposure that was estimated to be between 50 and $100 \mathrm{ppm}$ for about 10 seconds. This exposure was well below both the 8-hour PEL and 15-minute short-term exposure limit for ammonia, but the concentration was high enough to cause concern to the exposed worker. A technician was at the scene in minutes, and the problem was traced to a leak in the cover of the pit. The pit was sealed up the same day, and the potential for a similar incident eliminated.

Based on the exposure monitoring data collected to date, the release of vapors has remained relatively constant over time. This is in agreement with tank operating conditions, which have changed very little in the last several years. It is therefore likely that the tank vapor concentrations, and the releases of tank vapors, are similar to those observed in the 1987-1993 time frame.

The question could be asked, why were there so many employee exposure incidents a few years ago, and almost none occurring today? There are probably two reasons for this. First, the employee anxiety levels are much lower now than they were several years ago. Recent scientific studies have demonstrated that a worker's response to an odor is affected by the perceived risk associated with the odor. In other words, if a person believes an odor would make them sick, it often did. In addition, most of the odor incidents occurred after a shortterm exposure to an (apparently) high concentration of vapors. In order to be exposed to a high level of vapors, the employee would need to be working near a vapor release point. This was clearly possible in the 1987-1992 time frame, but would not occur after exposure controls were implemented in 1993 at known vapor release points.

Did overexposures occur during that time period? A definitive answer to this question is not possible. It is likely that workers did contact high levels of vapors for brief periods. However, since the tank farm vapors contain high levels of ammonia which is readily discernable and irritating, and also given the heightened sensitivity to these vapors, it is unlikely that any employee remained in an area of high vapor levels long enough to exceed PEL/TLV limits. 
The potential for vapor exposure is now understood. Current control measures prevent employee overexposures to vapors and minimize employee concerns regarding potential vapor exposure incidents. The vapor release points for each tank have now been identified and barricades have been erected around them. Any employee working within one of these barricades would have personal protective equipment or an industrial hygiene technician with monitoring instrumentation to determine if potentially harmful vapors are being released. Because of this, the likelihood for an employee being exposed to high vapor levels is much less than it was several years ago.

Although the same levels of vapors are probably being released from the tanks as previously, unprotected employees are not being exposed to these levels. The workers also know that with the present controls in place, the odors which are detected are unlikely to be harmful and if there is any question, an industrial hygiene technician is immediately available to verify the safety of the work place.

\subsection{OTHER TANK VAPOR ACTIVITIES}

Besides the previously mentioned Industrial Hygiene actions, another task intended to help correct hazardous vapors concerns was the Tank Vapor Issue Resolution Program. This program consisted of extensive studies to determine the nature of the vapor problem and take steps to reduce inhalation risk to employees. The program was to develop a tank vapor database, perform meteorological and tracer gas studies, and evaluate the use of vapor monitoring or mitigation equipment.

The program outlined by the Program Plan for the Resolution of Tank Vapor Issues, extended for several years. One of the options considered was to protect employee health during tank farm work by installing an exhaust system to remove and dilute the tank vapors. A Vapor Mixing System (VMS) was installed and is currently being tested in the C Tank Farm. Additionally, a statistical analysis is being conducted on tank vapor data to allow the current control measures to be further refined. Each of these activities is discussed below.

\subsection{VAPOR MIXING SYSTEM ON TANK 241-C-103}

Monitoring data shows that tank $241-\mathrm{C}-103$ releases some of the highest vapor concentrations of any tank at Hanford. These vapors are also among the most odorous of any tank, probably due to ammonia and the presence of organic chemicals which exhibit strong odors at low concentrations. These factors contribute to the fact that tank C-103 has had the greatest number of reported employee vapor exposures of any of the tanks. Because of this, there is a concern among workers that this tank presents a special hazard to employees working near it. 
WHC-SD-TWR-RPT-001

Revision 0

Page 15

While sampling and source monitoring data indicate that tank C-103 has vapor levels only slightly higher than other tanks, special controls have been implemented for this tank. While these controls have been effective in preventing both overexposures and exposure incidents, they have resulted in decreased worker productivity and added to operational costs.

The VMS was developed as a means of providing improved fugitive vapor emissions control at tank $\mathrm{C}-103$, while assuring that the concentration of released vapors remains below the PEL/TLV. The VMS draws a small amount of air from the tank headspace (nominal 20 $\mathrm{cfm}$ ), dilutes it with large volumes of ambient air, and exhausts it up a stack. The potential system benefits would be to eliminate tank fugitive emissions by maintaining the tank headspace at a slightly negative pressure, eliminate the need for routine monitoring during tank farm work, and provide cost savings due to increased worker efficiency and lower monitoring costs.

Initial system testing began in June 1995. This testing was inconclusive due to condensation of water in the tank high efficiency particulate air (HEPA) filter and housing, and because of failure of the low flow meter used for measuring tank airflow rate. These problems, caused the initial test to be suspended in late 1995. A new filter configuration has been prepared, and new flow monitoring equipment ordered. The VMS testing is scheduled for completion during FY-96. Depending on the test results, a decision will be made concerning future use of the VMS.

\subsection{TANK VAPOR DATA STATISTICAL EVALUATION}

As noted earlier, nearly all of the data from 1993 through 1994 consisted of industrial hygiene monitoring and sampling data collected near the tanks. This is because tank headspace sampling data were generally not available during this period. As a result, the risks were not well known and conservative control measures were implemented. Now that tank headspace results are available, it has been decided to perform a statistical analysis of all sampling and monitoring data collected to date (both tank headspace characterization and industrial hygiene).

This statistical evaluation will provide the best overall estimate of employee risks, since all monitoring data is included. By performing a statistical analysis of these data, proper control measures can be prescribed for each tank. In addition, by comparing data from all sources, on all tanks, the relative risks associated with different tanks can be categorized, and control measures recommended for groups of similar tanks.

The final phase of this study is currently in progress, and is expected to be completed in July 1996. After the study is completed, recommendations will be made for updating tank farm vapor control measures. These recommendations will probably be to further reduce the 
WHC-SD-TWR-RPT-001

Revision 0

Page 16

controls in a number of the tank farms. This is because exposure uncertainties have been included in existing control measures. As these uncertainties are removed by statistical analysis of all data, appropriate changes can be made to the controls. It is anticipated that updated recommendations will be prepared during the fourth quarter of FY96.

While the statistical study will allow for refinement of control measures, there is no indication that employees are not currently being protected from overexposure. Rather, existing control measures are overly conservative in protecting employees from vapor exposures. This conclusion is supported by personal vapor sampling of tank farm employees. As such, even prior to completion of the statistical analysis, it is clear that current control measures are sufficient to protect employees from overexposures.

\subsection{CONCLUSIONS}

In 1992, a number of questions were raised about the inhalation risks to employees from vapor exposure during work in tank farms. These questions resulted from several vapor exposure incidents and an elevated level of employee concern regarding their safety while working in tank farms. This, combined with a lack of information on tank headspace vapors and tank farm vapor exposure levels, caused WHC to initiate a strategy to reduce employee exposures to these vapors, to collect tank farm and tank headspace data, and to more accurately determine the risks of working near the waste storage tanks.

Based on 29 CFR 1910.120 requirements, actions were taken to:

- Generate a Tank Farm Health and Safety Plan (HASP)

- Develop a strategy to protect employees from potentially harmful vapor exposures

- Conduct a sampling program to evaluate the potential for vapor exposure and determine the actual exposure to the workers

Measures which have been implemented include the use of personal protective equipment where needed, utilizing vapor monitoring equipment with alarm capability during tank farm work, characterization of the tank headspace vapors so as to evaluate the potential for overexposure, and supervision of all aspects of the tank farm work by Industrial Health and Safety. The effort has been ongoing for over four years. A large amount of vapor data has been collected and evaluated resulting in several engineered and administrative improvements.

It has been determined from tank headspace, source, and area monitoring data that tank vapor levels at some locations in the tank farms are above acceptable exposure limits for a number 
of vapors, primarily ammonia and nitrous oxide. These vapors are escaping from the tanks at known release points and thus present a potential hazard to employees working near the tanks. However, barriers have been installed around these release points and based on the personal sampling and area monitoring results, these control measures are sufficient to prevent any employee overexposures to vapors. The tank vapor hazard has thus been identified, evaluated, and controlled. Employees are not at risk of vapor overexposure as long as appropriate control measures are continued.

In addition to the above, one of the vapors that is present in the tank headspace in highest concentrations is ammonia as determined from headspace characterization data. This vapor is very odorous, and can generally be detected by its odor at concentrations well below its PEL/TLV. Several of the other chemicals which have been identified in tank headspace sampling also have odor thresholds that are below their PEL/TLVs. Thus, even if a failure of control measures were to occur and employees were briefly exposed to an elevated ammonia level, they would be aware of the condition and would leave the tank farm and request that monitoring by an industrial hygiene technician be performed. Because of this, overexposure would be unlikely.

It should be noted that depending on a chemical's odor has several associated risks and should not be used as the primary means of employee protection. Therefore, prudent control measures will continue to be followed and modified as outlined by this report. Current personal sampling results and the lack of employee exposure incidents show that present controls are effective in preventing tank farm worker overexposures. Employee exposure incidents have virtually ceased due to implementation of controls around potential vapor release points and improved communications regarding vapor odors and risks.

Additional studies are not needed to verify these conclusions. Rather, continuing operations should focus on maintaining a safe work environment and being alert and receptive to new technologies which may offer more cost effective approaches to employee protection. 


\subsection{BIBLIOGRAPHY}

Apex Environmental, Inc., 1996, Exposure Monitoring Data Evaluation For The Hanford High Level Waste Tanks, Stage III: Tank Farms A, AX, BX, BY, C, S, TY and $U$.

Brown. D. H., S. R. Coleman, J. J. DeMeyer. P. A. Knight, R. C. Roa7, and S. J. Veitenheimer, 1992. Type B Investiqation of Hanford Tank Farms Vapor Exposures. U.S. Department of Energy, Richland Field Office, Richland, Washington.

Christensen. R. F., 1993, Enqineering Assessment of the Aerosol and Vapor Flammability in 241-C-103, (Letter 9303779 to President. Westinghouse Hanford Company. May 18, 1993). Department of Energy, Richland Operations Office. Richland, Washington.

Dukelow, G. T.. and G. A. Hanson, 1994. Status Report on Resolution of Waste Tank Safety Issues at the Hanford Site, WHC-EP-0600. Rev. 1. Westinghouse Hanford Company. Richland. Washington.

Farley. W. G., 1991, Safety Assessment for Gas Sampling A7l Ferrocyanide Tanks, WHC-SD-WM-SAD-009, Rev. 2, Westinghouse Hanford Company. Richland. Washington.

Gerton, R. E., 1992, Review of Westinghouse Hanford Company (WHC) Tank Vapor Program Plan. WHC-EP-0562. (Letter to President. Westinghouse Hanford Company. November 27, 1992), U.S. Department of Energy. Richland Field Office. Richland, Washington.

Hewitt. E. R., 1996, Tank Farm Health and Safety Plan. WHC-SD-WM-HSP-002, Rev. $2 E$. Westinghouse Hanford Company, Richland, Washington.

Huckaby, J. L.. 1994. Tank 241-C-103 Headspace Flammabi7ity, WHC-EP-0734. Rev. 1. Westinghouse Hanford Company, Richland. Washington.

Huckaby, J. L., 1994, Tank 241-C-111 Headspace Gas and Vapor Sample Results, Auqust 1993 Samples, WHC-SD-WM-TP-254. Rev. 0, Westinghouse Hanford Company. Richland. Washington.

Huckaby, J. L.. 1994, Vapor Characterization of Tank 241-C-103, WHC-EP-0780. Rev. 0. Westinghouse Hanford Company, Richland. Washington.

Huckaby, J. L.. 1994. Vapor Sampling System (VSS) and In Situ Sampling (ISS) Method Comparison. WHC-SD-WM-RPT-101. Rev. 0, Westinghouse Hanford Company. Richland. Washington. 
Huckaby, J. L., H. Babad, and D. R. Bratzel. 1995, Headspace Gas and Vapor Characterization Surmary for the 43 Vapor Proqram Suspect Tanks, WHC-SD-WM-ER514. Rev. 1B, UC-2070, Westinghouse Hanford Company, Richland. Washington.

Huggins. S. L.. 1995. Westinqhouse Hanford Company's Assessment Number AR95001 - PNL Laboratories, 9551457, Westinghouse Hanford Company. Richland. Washington.

Huggins, S. L., 1995. Westinghouse Hanford Company's Assessment Number AR95007 - Pacific Northwest Laboratory's, 9554892, Westinghouse Hanford Company. Richland, Washington.

Jenkins, R. A.. A. B. Dinda 7. C. E. Higgins, C. Y. Ma, J. T. Skeen, and R. R. Smith, 1994. Analysis of Tank 241-C-103 Headspace Components from Sampling Job 7B. Oak Ridge Nationa7 Laboratory, Oak Ridge. Tennessee.

Lerner, B. D. and K. H. Poo7, 1994, Waste Tank Safety Program Annual Status Report for FY 1993 Task 4: Inorganic Chemistry, PNL-8979-4 UC-606 UC-607. Pacific Northwest Laboratory, Richland. Washington.

Harmon H. D., 1993. Respirator Protective Requirements for Sinqle-Shell Tank Farms, (Letter 9350533 to J. H. Antonnen, RL. Apri7 13. 1993). Westinghouse Hanford Company. Richland. Washington.

Ligotke, M. W., 1995. PNL Vapor Project Analytical Holding Times, (Letter to D. R. Bratzel. WHC September 23, 1995), Pacific Northwest Laboratory.

Richland, Washington.

Ligotke, M. W. . T. R. Clauss, J. L. Huckaby, G. W. Dennis, R. B. Lucke, and S. C. Goheen. 1993. Aeroso 7 and Vapor Characterization of Tank 241-C-103:

Flammability Assessment Sampling System and Method Validation. PNL-8875 UC606, Pacific Northwest Laboratory, Richland. Washington.

Ligotke, M. W. T. R. Clauss, J. S. Fruchter. R. B. Lucke, G. W. Dennis, G. M. Mong. R. E. Hohimer, M. McCuulloch, M. T. Dana, and S. C. Goheen. 1994. Aerosol and Vapor Characterization of Tank 241-C-103: Data Report for in-Tank OVS Samples Obtained 12/02/93, PNL-9368 UC-606, Pacific Northwest Laboratory. Richland. Washington.

Lilga, M. A., E. V. Anderson, R. T. Hallen, M. O. Hogan. T. L. Huber, G. L. Jones, D. J. Kowalski. M. R. Lumetta, G. F. Schiefelvein, and M. R. Telander. 1995. Ferrocyanide Safety Project, Ferrocyanide Aqinq Studies FY 1995 Annual Report, PNL-10713. Pacific Northwest Laboratory, Richland, Washington.

Mahon, R. D. C. M. Jones, and M. S. Story, 1994, Evaluation of the Capabilities and Use of the Vapor Sampling System for Tank Headspace Sampling and Characterization. WHC-SD-WM-RPT-094, Rev. 0. Westinghouse Hanford Company. Richland, Washington. 
WHC-SD-TWR-RPT-001

Revision 0

Page 20

Mah7um. D. D., J. Y. Young, and R. E. Weller, 1994. Toxicologic Evaluation of Analytes from Tank 241-C-103. PNL-10189. Pacific Northwest Laboratory.

Richland. Washington.

O'Leary, H. R. . 1993. Hanford Tank Waste Remediation System Safety

Initiatives, U.S. Department of Energy, Washington, D.C., September 17, 1993.

Osborne, J. W. and J. L. Huckaby, 1994, Program Plan for the Resolution of

Tank Vapor Issues, WHC-EP-0562, Rev. 1. UC-600. Westinghouse Hanford Company. Richland. Washington.

Osborne, J. W. J. L. Huckaby. T. P. Rudolph, E. R. Hewitt, D. D. Mahlum. B. J. Y. Young, and M. S. Anderson, 1994. Tank 241-C-103 Vapor and GaS Sampling DOO'S, WHC-EP-0774. Rev. O. Westinghouse Hanford Company. Richland. Washington.

Osborne, J. W. J. L. Huckaby, T. P. Rudolph, E. R. Hewitt, D. D. Mah7um, J. $Y$. Young. and M. S. Anderson. 1995, Data Quality Objectives for Generic InTank Health and Safety Vapor Issue Resolution, WHC-SD-WM-D00-002, Rev. 1, Westinghouse Hanford Company, Richland. Washington.

Postma, A. K., D. B. Bechtold, G. L.Borsheim. J. M. Grigsby, R. L. Guthrie, M. Kummerer. M. G. Plys, and D. A. Turner, 1994. Safety Analysis of Exothermic Reaction Hazards Associated with the Orqanic Liquid Layer in Tank 241-C-103. WHC-SD-WM-SARR-001. Rev. 0, Westinghouse Hanford Company, Richland, Washington.

Price, D. N., 1994. Rotary Samoling Core Vapor Samp7ing Data Quality Objectives, WHC-SD-WM-SP-003, Rev. O, Westinghouse Hanford Company, Richland, Washington.

Rasmussen. R. A., and W. Enfield, 1994. Hanford Tank 103-C Analysis and Method Validation Development Phase, SAND94-1807. Sandia Nationa7 Laboratories, Albuquerque, New Mexico.

Sager. R. P.. 1992. Hydrogen Cyanide Off-Gassing from Ferrocyanide Waste Tanks, (Letter 9200668 to President, Westinghouse Hanford Company, January 29, 1992). Department of Energy. Richland Operations Office, Richland. Washington.

Tus7er, L. A.. 1994, Waste Tank Characterization Sampling Limits, WHC-50-WMTI-651, Westinghouse Hanford Company, Richland. Washington. 


\section{DISTRIBUTION SHEET}

\begin{tabular}{|c|c|c|c|c|c|}
\hline \multirow{2}{*}{$\begin{array}{l}\text { To } \\
\text { Distribution }\end{array}$} & \multirow{2}{*}{\multicolumn{3}{|c|}{$\begin{array}{l}\text { From } \\
\text { TWRS Safety }\end{array}$}} & \multicolumn{2}{|c|}{ Page 1 of 1} \\
\hline & & & & \multicolumn{2}{|c|}{ Date June 28, 1996} \\
\hline \multirow{2}{*}{\multicolumn{4}{|c|}{$\begin{array}{l}\text { Project Title/Work Order } \\
\text { WHC-SD-TWR-RPT-001, Re } \\
\text { Resolution of Potentia }\end{array}$}} & \multirow{2}{*}{\multicolumn{2}{|c|}{$\begin{array}{ll}\text { EDT No. } & 615284 \\
\text { ECN No. } & N / A\end{array}$}} \\
\hline & & & & & \\
\hline Name & MSIN & $\begin{array}{l}\text { Text } \\
\text { With Al! } \\
\text { Attach. }\end{array}$ & Text Only & $\begin{array}{l}\text { Attach./ } \\
\text { Appendix } \\
\text { Only }\end{array}$ & $\begin{array}{c}\text { EDT/ECN } \\
\text { Only }\end{array}$ \\
\hline $\begin{array}{l}\text { M. A. Andersch } \\
\text { S. L. Bump } \\
\text { D. R. Carls } \\
\text { L. M. Calderon } \\
\text { G. L. Dunford } \\
\text { J. E. Geary } \\
\text { S. S. Glover } \\
\text { G. Gottfried } \\
\text { M. T. Hughey } \\
\text { J. A. Hubbard } \\
\text { D. H. Irby (5 copies) } \\
\text { M. N. Islam } \\
\text { S. J. Lijek } \\
\text { J. K. McClusky } \\
\text { R. D. Mitchell } \\
\text { S. T. Murff } \\
\text { R. L. Nelson } \\
\text { C. O. Olaiya } \\
\text { J. W. Osborne } \\
\text { J. C. Peschong } \\
\text { D. P. Reber } \\
\text { W. E. Ross } \\
\text { M. J. Royack (2 copies) } \\
\text { A. B. Sidpara } \\
\text { D. Simpson } \\
\text { D. Squires } \\
\text { L. E. Thomas }\end{array}$ & $\begin{array}{l}\text { R3-01 } \\
\text { T4-08 } \\
\text { R3-01 } \\
\text { R3-01 } \\
\text { A2-34 } \\
\text { S5-07 } \\
\text { T4-08 } \\
\text { S2-42 } \\
\text { R3-12 } \\
\text { R2-54 } \\
\text { S7-54 } \\
\text { R3-08 } \\
\text { S7-73 } \\
\text { S7-54 } \\
\text { T4-08 } \\
\text { S7-73 } \\
\text { R3-54 } \\
\text { S7-54 } \\
\text { X3-80 } \\
\text { S7-54 } \\
\text { T4-07 } \\
\text { S5-07 } \\
\text { S7-54 } \\
\text { S7-54 } \\
\text { A2-34 } \\
\text { S7-54 } \\
\text { R3-08 }\end{array}$ & $\begin{array}{l}x \\
x \\
x \\
x \\
x \\
x \\
x \\
x \\
x \\
x \\
x \\
x \\
x \\
x \\
x \\
x \\
x \\
x \\
x \\
x \\
x \\
x \\
x \\
x \\
x \\
x \\
x\end{array}$ & & & \\
\hline
\end{tabular}

